\title{
CHARACTERISTICS OF THE BERGSCHRUND OF AN AVALANCHE-CONE GLACIER IN THE CANADIAN ROCKY MOUNTAINS
}

\author{
By Gerald OSBORN \\ (Department of Geology and Geophysics, University of Calgary, Calgary, Alberta T2N 1N4, \\ Canada)
}

Aвstract. Field study of the bergschrund of a small avalanche-cone glacier at the base of Mt Chephren, in Banff National Park, has been carried out as part of a general exploratory study of glacier-head crevasses in the Canadian Rockies. The bergschrund consists of a wide, shallow, partly bedrock-floored gap, underneath which extends a nearly vertical Randkluft, and a small, offset, subsidiary crevasse (or crevasses). The following observations regarding the behavior of the bergschrund and ice adjacent to it are of particular interest: (1) topography of the subglacial bedrock is a control on the location of the main bergschrund and subsidiary crevasses, (2) the main bergschrund and subsidiary crevasse(s) are connected by subglacial gaps between bedrock and ice; the gaps are part of the "bergschrund system", (3) snow/ice immediately down-glacier of the bergschrund system moves nearly vertically downward in response to rotational flow of the glacier, allowing the bergschrund components to keep the same location and size from year to year, (4) an independent accumulation, flow, and ablation system exists in the snow/ice up-glacier of the bergschrund system, (5) most of the void space in the bergschrund system is maintained through the winter, although the wide, shallow part of the main bergschrund fills up with snow, (6) some mass transfer of snow/ice occurs across the bergschrund system, (7) displacement across the bergschrund due to flow of the main glacier body results in significantly more snow being deposited each winter down-glacier of the bergschrund than up-glacier of it.

RÉSUMÉ. Caracterristiques de la rimaye d'un glacier formé par un cône d'avalanche dans les Montagnes Rocheuses Canadiennes. On a conduit une étude sur le terrain de la rimaye d'un petit glacier formé par un cône d'avalanche, dans le cadre d'une étude générale exploratoire des rimayes dans les Rocheuses Canadiennes. Le glacier se situe au pied de la paroi nord-est du Mt Chephren dans le Parc National de Banff. La principale rimaye consiste en un espace large peu profond allant en partie jusqu'au bedrock, sous laquelle s'étend une crevasse presque verticale entre le bedrock et le corps principal du glacier. La rimaye sétrangle avant d'atteindre le côté sud-est du cône, mais de petites crevasses annexes la poursuivent dans une zone déclive. La localisation de la rimaye principale et des crevasses annexes est en partie liée à la topographie du bedrock sous-jacent. Les observations suivantes concernant le comportement de la rimaye et de la glace avoisinante offrent un intérêt particulier: (1) la rimaye principale et les crevasses annexes sont toutes reliẻes par des cavités sous-glaciaires entre le bedrock et la glace, ces cavités font partie du systeme de la rimaye, (2) l'ablation se produit pendant l'été à la surface des glaces profondes aussi bien que sur la surface supérieure du glacier, (3) la neige devenant glace immédiatement en-dessous du système de la rimaye se déplace presque verticalement en raison de l'écoulement rotationnel du glacier, ce qui permet au systeme de la rimaye de conserver la même localisation et la même forme d'année en année, (4) un système indépendant écoulement-ablation existe dans le névé au-dessus du systéme de la rimaye, (5) la plus grande partie de l'espace vide dans le système de la rimaye se maintient pendant l'hiver bien que la portion large et peu profonde de la rimaye principale se remplisse de neige, (6) un certain transfert de masse de névé se produit à travers le système de la rimaye. (7) le déplacement à travers la rimaye dû á l'écoulement aboutit à ce qu'il se dépose de manière significative, plus de neige chaque année en-dessous de la rimaye qu'au dessus.

ZuSAMmenfassung. Charakteristiken des Bergschrundes eines Lawinenkegelgletschers in den Kanadischen Rocky Mountains. Felduntersuchungen des Bergschrundes an einem kleinen Lawinenkegelgletscher wurden als Teil einer allgemeinen Studie der zungenfernen Gletscherspalten in den Kanadischen Rocky Mountains durchgeführt. Der Gletscher liegt am Fusse der Nordostflanke des Mt Chephren im Banff National Park. Der Haupt-Bergschrund besteht aus einer weiten, seichten Spalte, teilweise über Felsgrund, unter der sich eine fast senkrechte Kluft zwischen dem Fels und dem eigentlichen Gletscherköper erstreckt. Der Bergschrund streicht aus, bevor er die Südostseite des Kegels erreicht, setzt sich aber in kleinen, gestaffelten Nebenspalten fort. Die Lage des Haupt-Bergschrundes und der Nebenspalten steht teilweise im Zusammenhang mit der Topographie des Felsuntergrundes. Die folgenden Beobachtungen über den Bergschrund und das ihm benachbarte Eis dürften von 
besonderem Interesse sein: (1) Der Haupt-Bergschrund und seine Nebenspalten sind durchwegs durch subglaziale Lücken zwischen Fels und Eis miteinander verbunden; die Lücken sind ein Teil des "Bergschrundsystems". (2) Ablation tritt im Sommer an den subglazialen Eisoberflächen ebenso auf wie an der Gletscheroberfläche. (3) Schnee und Eis unmittelbar unter dem Bergschrundsystem bewegt sich nahezu senkrecht nach unten infolge des rotierenden Gletscherflusses, wodurch die Bergschrundkomponenten von Jahr dieselbe Lage und Grösse beibehalten können. (4) In Schnee und Eis über dem Bergschrundsystem besteht ein eigenes Fluss- und Ablationssystem. (5) Ein Grossteil des Leerraumes im Bergschrundsystem bleibt auch im Winter offen, obwohl der weite, seichte Teil des Hauptbergschrundes sich mit Schnee füllt. (6) Ein gewisser Transport von Schnee und Eis findet auch über das Bergschrundsystem statt. (7) Verlagerungen über den Bergschrund infolge von Fliessbewegungen führen im Winter zu wesentlich grösseren Schneeablagerungen unter dem Bergschrund als über ihm.

\section{INTRODUCTION}

"Bergschrund" has been defined as "the crevasse occurring at the head of a mountain glacier, which separates the moving snow and ice of the glacier from the relatively immobile snow and ice adhering to the headwall of the valley" (American Geological Institute, 1962). Despite the fact that bergschrunds are the most obvious structural features on many cirque and valley glaciers, very little is known about their general characteristics and behavior, and about the nature of ice motion immediately up-glacier and down-glacier of them. The bergschrund, according to Battle and Lewis (1951), "resembles a living organism with a life-cycle concerning which we are extremely ignorant". While aspects of particular bergschrunds or Randklüfte have been described in the literature (e.g. Battle, 1952; Battle and Lewis, 1951; McCall, 1960), most prior field study in and of glacier-head gaps has concentrated on thermal regimes in the gaps and associated problems of cirque headwall erosion.

This paper presents some observations of a particular bergschrund, and behavior of the ice adjacent to it. Field study took place during the summers of 1977, 1978, and 1979. Difficult and hazardous working conditions (probably one reason why bergschrunds have received so little attention) limited the amount of data that could be gathered and necessitate considerable speculation; nevertheless some interesting findings have emerged.

\section{The Mt Chephren site}

The bergschrund described here occurs in a very small avalanche-cone glacier rather than a typical cirque glacier. The glacier is the north-westernmost of three small glaciers fed by avalanches from the north-east flank of Mt Chephren, in Banff National Park, Alberta (Fig. 1). The elevation of the toe is about $1960 \mathrm{~m}$. The $150 \mathrm{~m}$-long glacier retains a shape appropriate to its avalanche-cone genesis (Fig. 2) but contains the normal accoutrements of a cirque glacier, including sedimentary layering in the ice which dips up-glacier near the toe, and, of course, the bergschrund. Peripheral to the base of the cone is a moraine undoubtedly built during the Cavell Advance of the last few centuries (Luckman and Osborn, 1979). Observations suggest that direct snow-fall plays an insignificant role in nourishment of the glacier; the snow which persists through the summer season is mostly avalanche snow. Small avalanches (such as are common in the fall and spring) spread out over only part of the cone; larger avalanches cover the entire cone. In summer a stream descending the avalanche chute melts a tunnel into the apex, and summer avalanches disappear into the hole. Nourishment by funneled avalanches results in two peculiarities on this glacier: (1) some avalanches erode older snow near the apex before 


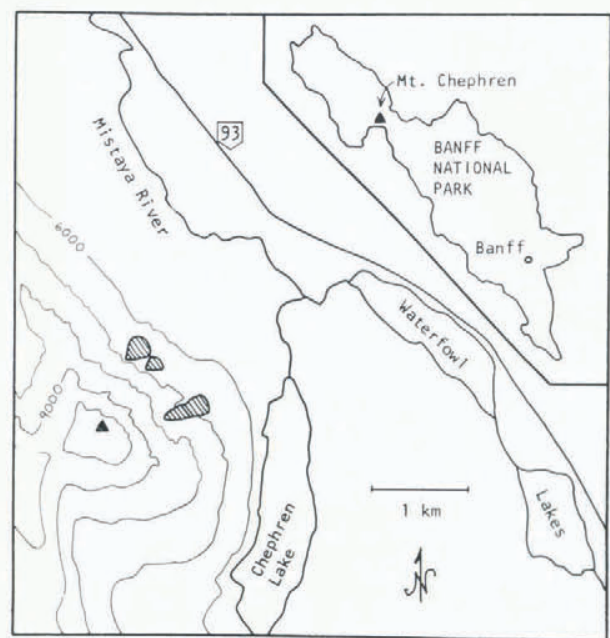

Fig. 1. Location map, with inset of Banff National Park. Mt Chephren is outlined by contours in lower left ( 1000 feet $(305 \mathrm{~m})$ contour interval); summit marked by solid triangle. Hatched areas represent cone glaciers at the base of the north-east flank of the mountain.

depositing their own snow, resulting in stratigraphic irregularities that make it difficult to distinguish annual layers up-glacier of the bergschrund, (2) summer melting exposes an irregular patchwork of avalanche layers (Fig. 2).

The appearance of the bergschrund in late summer is that of a gaping crack which splits the north-west side of the cone but pinches out on the south-east side. Bedrock, or rock rubble lying on bedrock, is exposed at the bottom along most of the bergschrund's length. Figure 3 shows the nature of the open part of the bergschrund. On the south-east end (Fig. 3a) both the up-glacier and down-glacier walls are of similar height $(2$ to $3 \mathrm{~m})$ but to the north-west the up-glacier wall overhangs and rises in height to $10 \mathrm{~m}$ while the down-glacier wall flattens into a platform (Fig. 3 b). A cross-section through the north-west end is shown in Figure 4. Here the down-glacier ice is separated from a near-vertical wall of bedrock by a Randkluft-style gap with a width of about

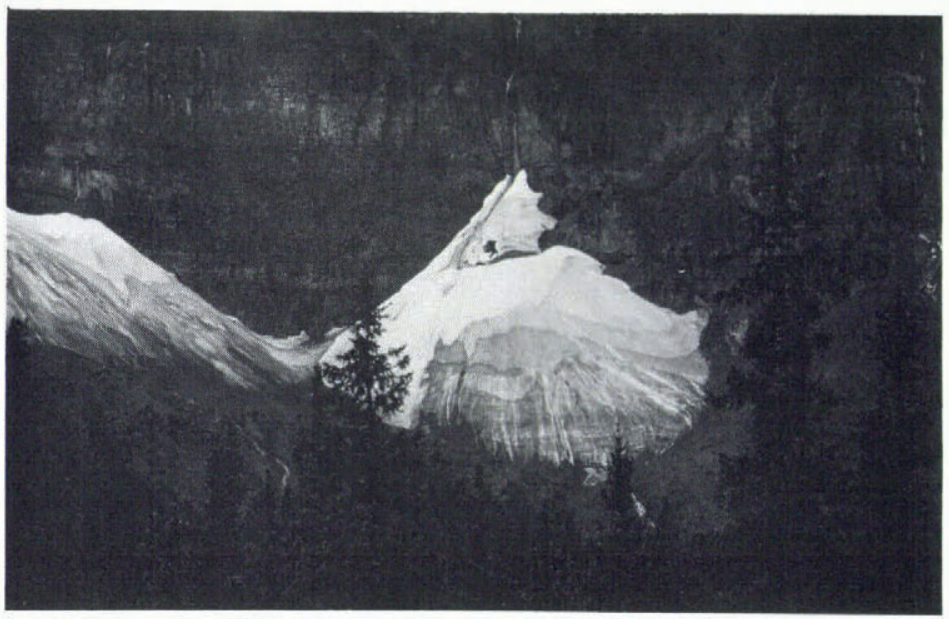

Fig. 2. View of the glacier from Highway 93. Bedrock is visible at the bottom of the gaping bergschrund. A lightlyvegetated end moraine can be seen between the foreground trees and the glacier. Photograph taken 6 September 1978. 

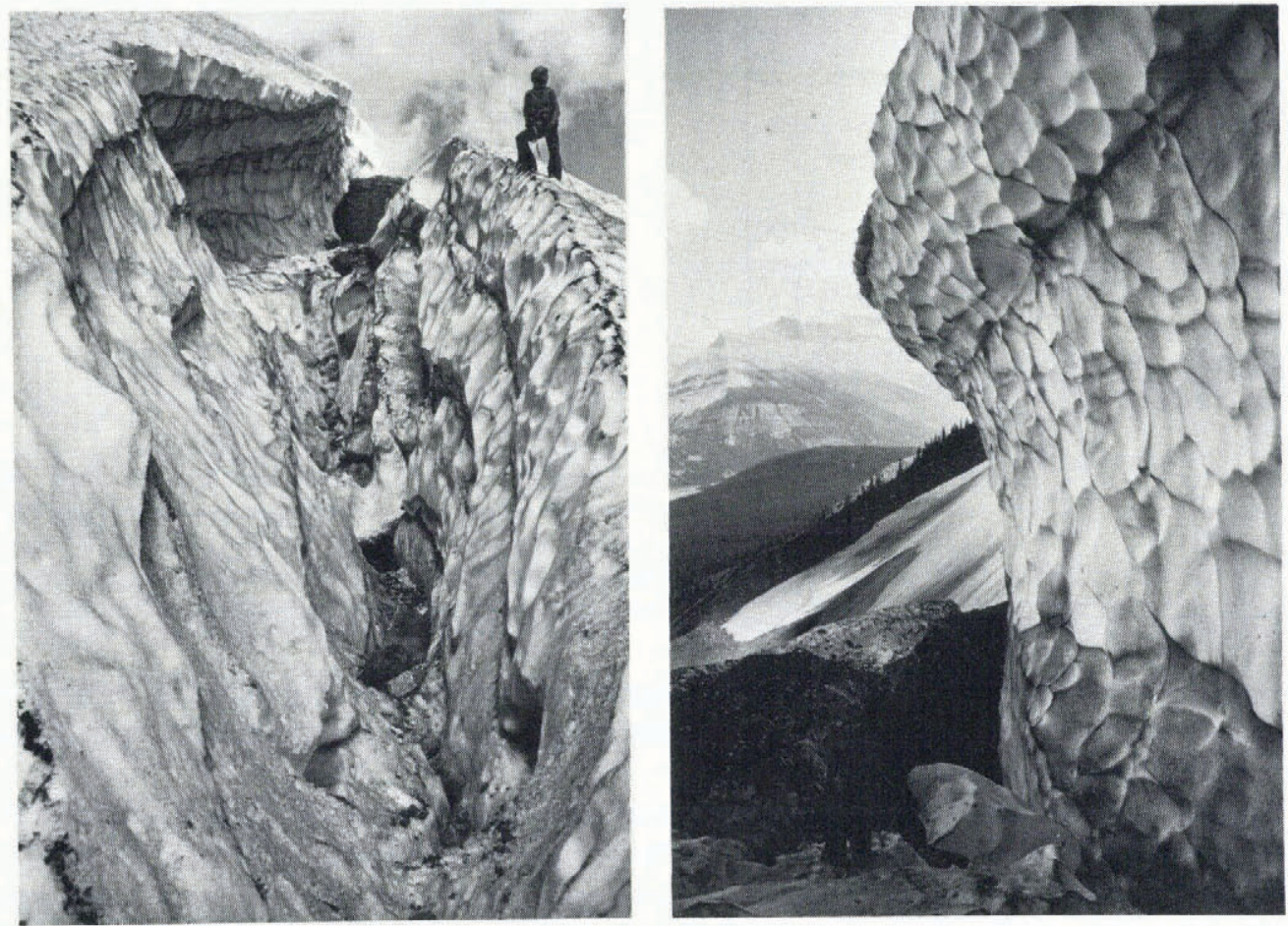

Fig. 3. The nature of the bergschrund in late summer. Photographs taken in August 1977. (a) South-east end. (b) North-west end. Field assistant (lower left) is standing on platform referred to in text.

$2.5 \mathrm{~m}$ and some unknown depth greater than $35 \mathrm{~m}$. This gap gradually closes to the south-east, and in the middle part of the bergschrund there are only occasional small holes separating downglacier ice from bedrock (Fig. 5).

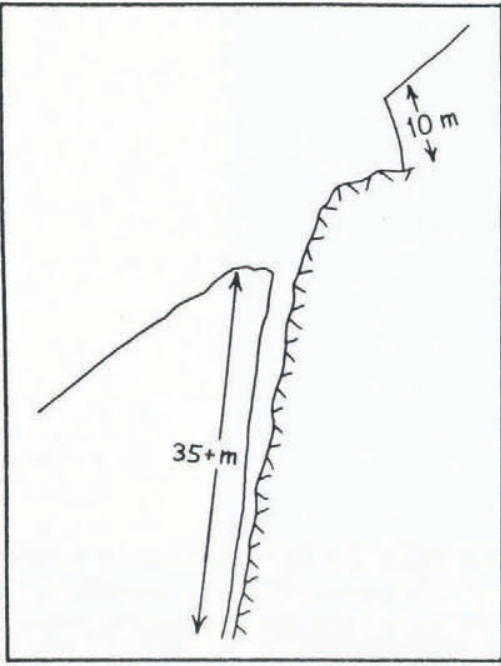

Fig. 4. Cross-section through the north-western end of the bergschrund. 


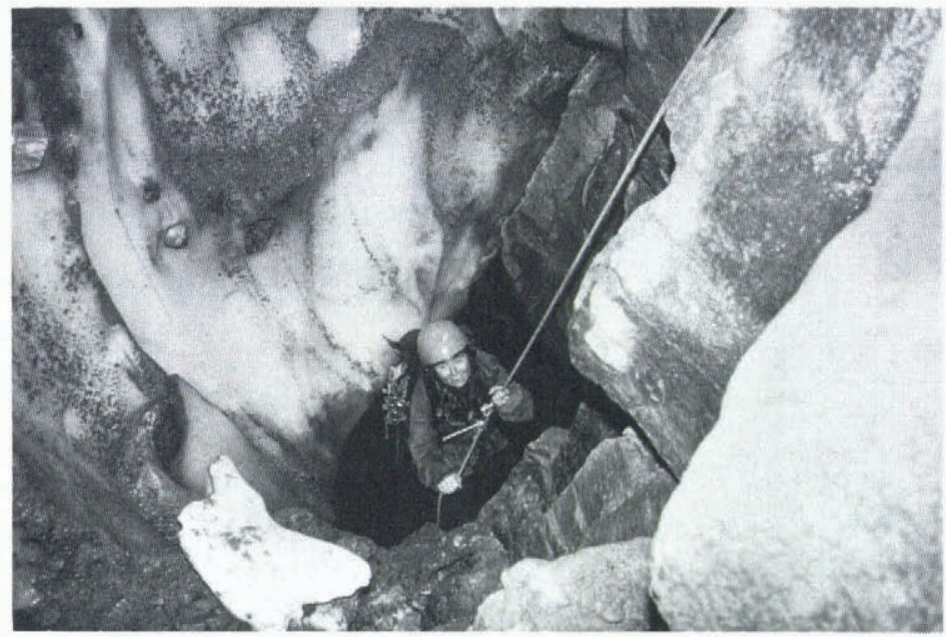

Fig. 5. Hole between main glacier body and bedrock, leading to subglacial cavity. Photograph taken 27 August 1977.

The material exposed in the up-glacier wall appears to be mostly firn, in part consolidated by melting and refreezing, with the snow layer of the previous winter on top. On its south-east end the wall exposes sedimentary layering that is often irregular and difficult to trace from point to point (Fig. 3a). These layers may relate to individual avalanches. Layers that are laterally uniform and of consistent thickness, such as those that occur on the north-west end (Fig. 3b) are probably annual layers. The down-glacier wall or platform is neither high nor clean enough to show any layering, except at its south-east end.

In very late summer a thin crevasse (or crevasses) appears slightly down-glacier and to the south-east of the end of the bergschrund (Fig. 6). Exploration showed that this crevasse was an

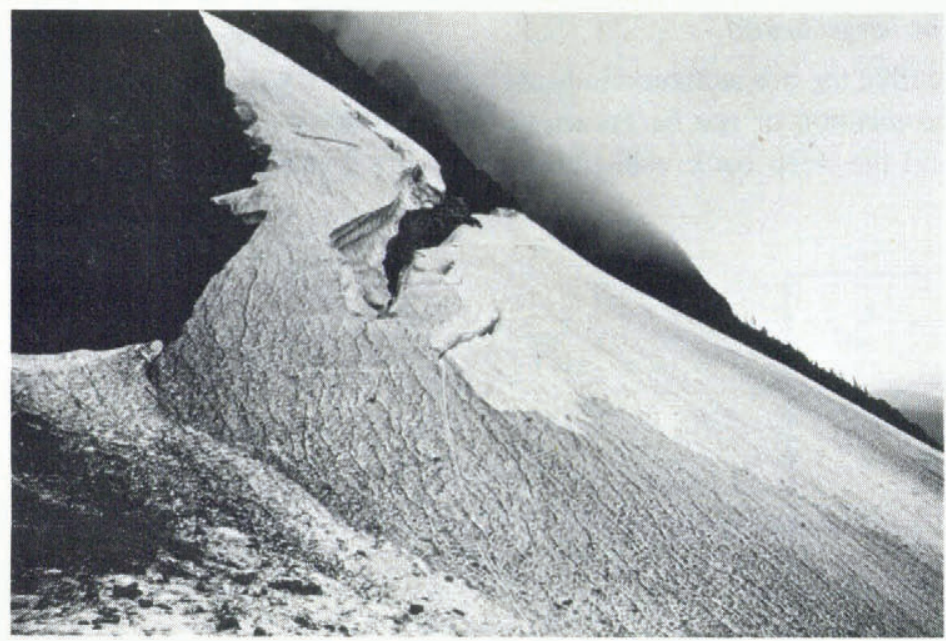

Fig. 6. Side view of glacier, looking north-west, showing small crevasse opening down-glacier of south-east end of bergschrund. Photograph taken 24 September 1977. 


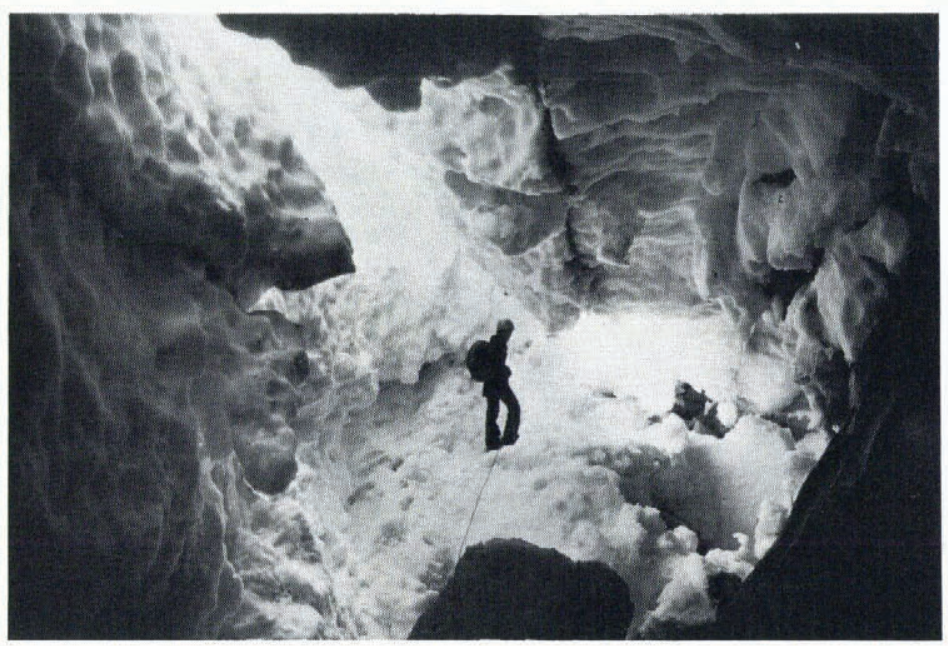

Fig. 7. The interior of the crevasse shown in Fig. 6, looking south-east (the down-glacier direction is to the left). Dark bedrock appears in lower right. Photograph taken 24 September 1977.

offset continuation of the bergschrund. Figure 7 is a photograph of the crevasse, and a typical cross-section is shown in Figure 8. Of note is a steepening of the bedrock at the site.

\section{BEHAVIOR OF ICE IN AND NEAR THE BERGSCHRUND SYSTEM}

Several points relating to the origin of the bergschrund and subsidiary gaps, and dynamics of the ice up- and down-glacier of it, will be dealt with in the following sections.

\section{The location of the bergschrund}

Exploration within the bergschrund indicated that geometry of the bedrock is a major control on the nature and location of the bergschrund and subsidiary crevasses. On the north-west end of the bergschrund the steep rock wall shown in Figure 4 controls the locations; the top of the

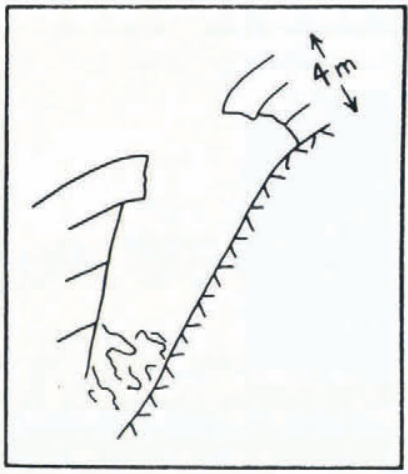

Fig. 8. Typical cross-section of a crevasse such as that shown in Fig. 7, looking south-east. The crevasse is bounded on the left by glacier ice and on the right by bedrock, and is floored by block-ice rubble. 
wall separates relatively thin up-glacier ice from the main body of the glacier. To the south-east the steep wall becomes more irregular, eventually bending outward (i.e. towards the north-east) as shown in Figure 9. As a consequence the bergschrund ends shortly beyond.

The thin subsidiary crevasse (Figs 6 and 7) was also located along a steep bedrock wall. That this wall was an offset segment of the above-mentioned rock wall was determined by subglacial mapping. In 1977 the hole shown in Figure 5 (which started at the bottom of the shallow part of the bergschrund) led down $10 \mathrm{~m}$ to the ice-rubble floor of a room bounded partly by bedrock and partly by firn and ice. A subglacial gap along the bedrock wall joined this room to the thin crevasse (Fig. 9). Another subglacial cavity, not quite wide enough to permit human passage, continued underneath the thin crack seen running down the fall line in Figure 6 . This cavity/crack system was also controlled, at least along its west end, by steep bedrock. Thus offsets of the crevasses are consequent to offsets of the rock wall.

The subglacial gaps, which were also observed in succeeding years, become bergschrund segments if and when they are de-roofed by ablation. In transverse cross-sections they are widest at the bottom and narrowest at the top (Fig. 10); they are in effect inverse crevasses, opening at the glacier's sole instead of its surface. As such they differ from the subglacial cavities roofed by rather smooth ice ceilings that are sometimes found in the lee of rock steps under thick glacier ice (e.g. Vivian and Bocquet, 1973; Theakstone, 1979).

Characteristic of the subglacial gaps is the cupped appearance of their ice surfaces (e.g. Fig. 10). The hollows are presumably formed by wastage of the ice, accomplished by heat circulating from adjacent crevasses. No melt water dripping off the ceilings was seen at points well inside the sub-glacial gaps, so either melt water is evaporated or the ice sublimates.

The surface crevasses and subglacial gaps together constitute what could be considered a "bergschrund system", which separates the main glacier body from thinner ice up-glacier of the rock step. This system becomes less obvious on the south-east side of the glacier apparently because the rock step decreases in size (and slightly in steepness) on that side. The actual mechanical origin of both the crevasses and subglacial gaps is displacement and fracturing of the ice as it drops over the rock step. Displacement was indicated by offsets of distinctive clearice/bubbly-ice foliation patterns.

\section{Ice/snow motion down-glacier of the bergschrund}

The deep, narrow gap between glacier ice and bedrock in the north-western half of the bergschrund, does not increase in width from year to year. Therefore the glacier cannot be

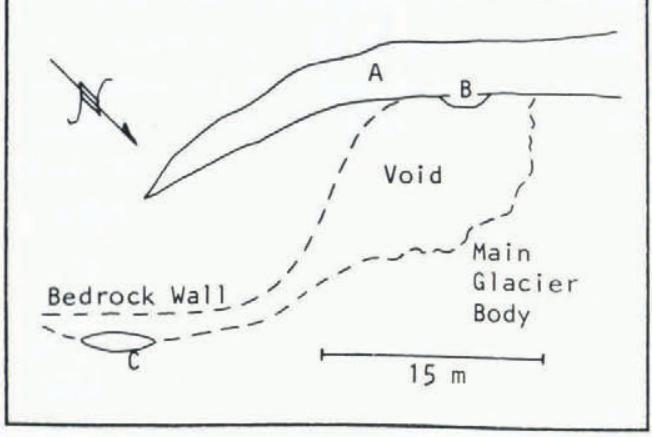

Fig. 9. Plan-view sketch showing how crevasse phenomena are related to $a$ bend in the bedrock wall. Solid lines are surface features; dashed lines are subsurface features not visible from the glacier surface. (A) South-eastern part of the bergschrund. (B) Hole shown in Fig. 5. (C) Crevasse shown in Fig. 7. 


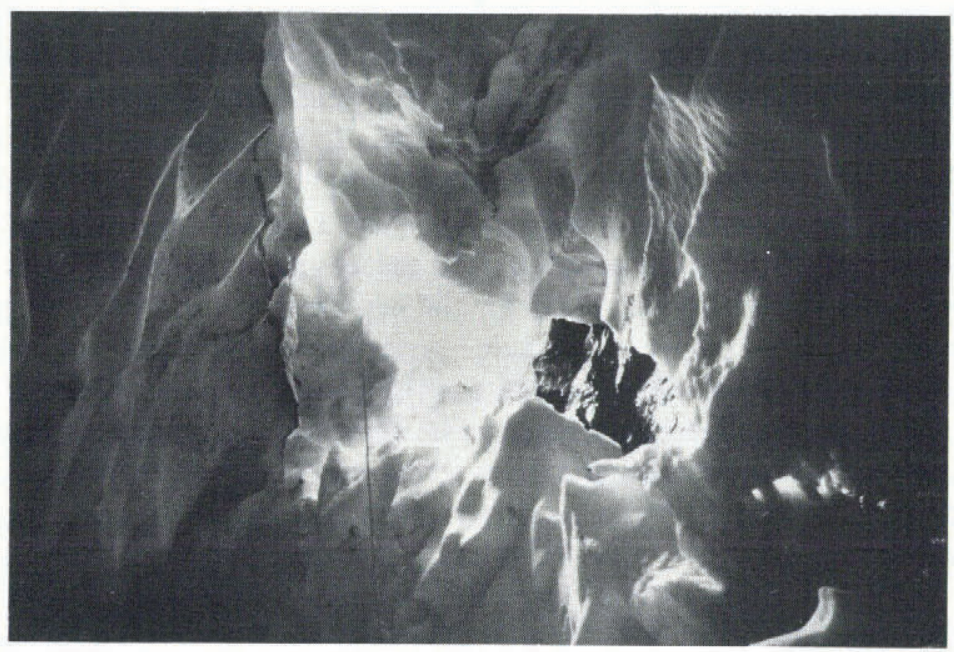

Fig. 10. Subglacial gap, looking horizontally (and south-east) along length of gap. Bedrock is exposed right of center. The scalloped face on left of photo is the lower surface (i.e., the bottom) of an annual layer which is being breached by the large crack to the left top center. Photograph taken 18 A ugust 1978. Width of area in foreground is approximately $2.5 \mathrm{~m}$.

pulling away from the bergschrund in a direction parallel to the glacier surface. In late summer the glacier surface is displaced downward by roughly $2 \mathrm{~m}$, relative to the surface up-glacier of the bergschrund, while after the winter snow-fall season no displacement can be observed. This indicates that the ice and snow down-glacier of the bergschrund moves downward, more or less parallel to the bedrock wall. This downward displacement, coupled with the up-glacier dip of annual layers near the toe, indicates that the glacier flows with the rotational aspect described by McCall (1960). On the south-east side of the glacier the rock is more irregular and the pattern of ice motion not as clear-cut; nevertheless displacements of fractions of a metre of both the glacier surface and ice foliation were observed across the small crevasses beyond the end of the bergschrund.

Layering in the main glacier body was well exposed in the small subsidiary crevasse in 1977, and less well exposed in the equivalent crevasse in 1978. The 1977 scene is shown in Figure 11. What appear to be four annual layers, each 1.5 to $2 \mathrm{~m}$ thick, are exposed. The bottom-most is partly obscured by snow and blocks of firn. In an attempt to mark the layers, for purposes of reference the following year, a long wooden dowel was placed in the third annual layer. Unfortunately, the following year no trace of the dowel was found and only two layers were exposed above the then larger pile of firn blocks. But despite the lack of quantitative data, it appears likely that the ice layers shown in Figure 11 move nearly vertically downward as the glacier flows, while the displacement across the crevasse is masked each winter by new snow.

\section{Ice/snow motion up-glacier of the bergschrund}

Figure 7 shows the ice layers on the up-glacier side of the crevasse of Figure 11. Three layers, folded downward to a vertical orientation, were observed. The uppermost layer is equivalent to the uppermost down-glacier layer; the two in fact join to make a single unbroken 


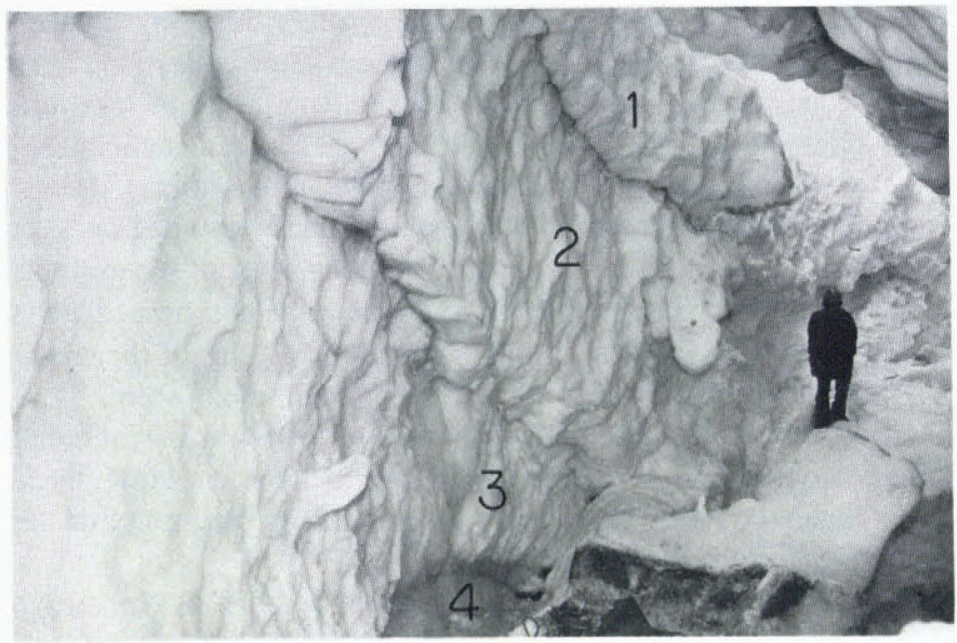

Fig. 11. Four annual layers (numbered in sequence) on the down-glacier side of the crevasse shown in Fig. 8. Photograph taken with flash 24 September 1977.

layer outside the picture area. The second and third layers presumably also are equivalent on either side of the crevasse. The third layer on the up-glacier side is quite thin however.

The ice wall that exposes the up-glacier layers (to the right of the assistant's head in Figure 7) was observed to ablate back during the 1977 season relative to englacial stones, yet the ice wall did not move significantly relative to the bedrock. In 1978 only two layers were seen on the upglacier side; they too ablated while the ice wall stayed in the same place. These observations suggest that (a) only a small number of layers are ever present on the up-glacier side of the crevasse, and (b) these layers must move down the bedrock slope to balance the ablation and keep the ice wall in an equilibrium position. Hence, the ice and snow above the crevasse must have its own independent system of flow and mass balance. A hypothesis developed by $\mathrm{C}$. Langill to relate the flow systems above and below the crevasse (or subglacial gap) is shown in Figure 12. Above the crevasse or gap, annual layers pinch out depositionally against the bedrock

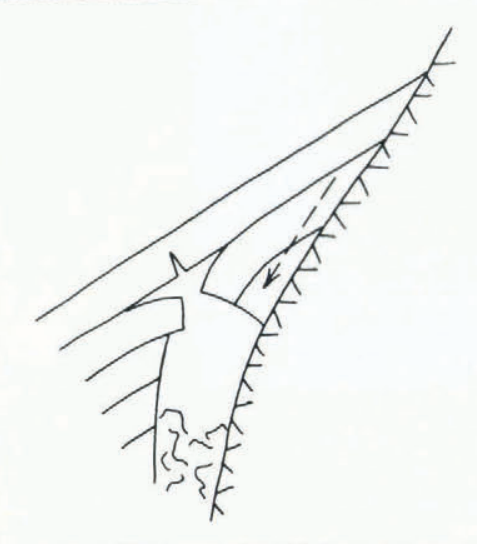

Fig. 12. Flow system up-glacier of the south-eastern part of the bergschrund system. While the main glacier body moves downward, the snow/ice up-glacier of the gap creeps down the bedrock surface in the direction of the arrow. Meanwhile, ablation results in backwearing of the up-glacier ice-wall, thus keeping the ice-wall in about the same position. 
slope. The layers slowly creep or flow downhill (perhaps lubricated by a basal water layer) but their faces ablate in the crevasse or gap. Thus the bottom layer is destined always to disappear. Meanwhile, across the crevasse or gap, the layers are moving more or less vertically downward as the main glacier body flows. The topmost layer, which bridged the gap the previous winter, begins to fold downward into the void and crack. If the crack breaks through to the surface (aided by ablational thinning of the layer) what was a subglacial gap becomes a crevasse, and the crack/crevasse extends itself lengthwise through the melting season. An example of this cracking process is shown in Figure 13. This hypothesis accounts for the perpetually small number of layers (be they annual layers or single-avalanche layers) up-glacier of the crevasse or gap: while new ones are being added on top, old ones are disappearing on the bottom.

Farther to the north-west, the high up-glacier wall of the main bergschrund is layered (Fig. $3 \mathrm{~b}$ ), and a similar process must be operating there. The ice/snow thickness above the bergschrund stays roughly constant from year to year, so any new material added on top must be balanced by subtraction from the bottom.

The steady-state regulation envisioned here seems to hold on a year-to-year basis, but not necessarily a season-to-season basis; the question of what happens in winter is raised below.

\section{The bergschrund system through the seasons}

The subglacial gaps on the south-east end of the system were, during the years of field study, in existence in the middle part of each summer, before crevasses opened at the surface. Thus these gaps probably persist year-round. Crevasses that open in the late summer no doubt will admit some new autumn snow (and avalanche snow) into the gaps, but the crevasses are probably bridged fairly quickly, preventing further filling of the gaps. Insofar as the snow and ice up-glacier of the gaps may vary in terms of flow and ablation from season to season and year to year, there might be small variations in size and position of the gaps from year to year.

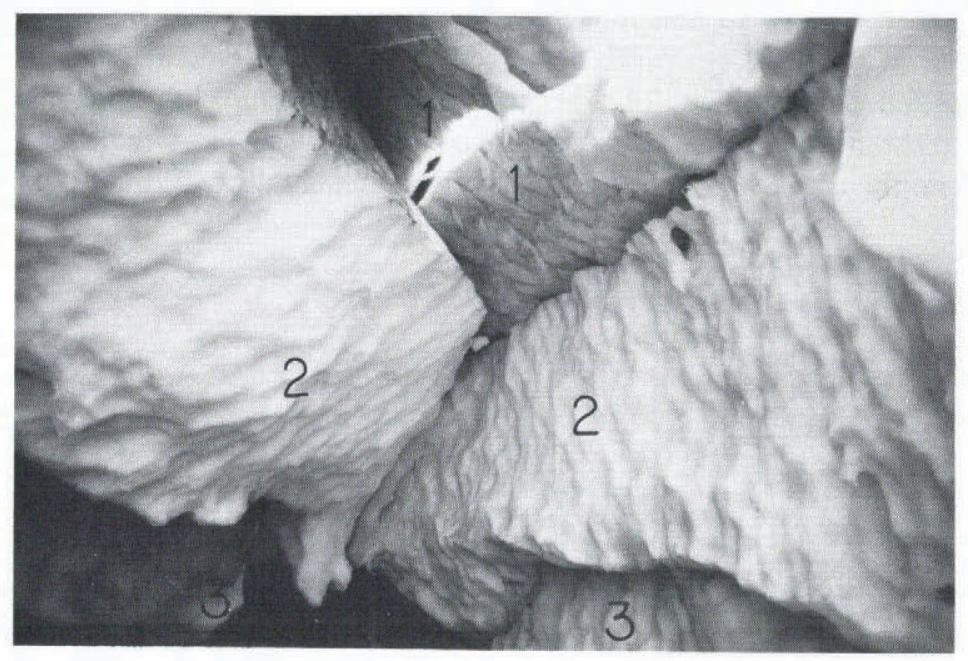

Fig. 13. Cracking of roof of subglacial gap. Annual layers are numbered in sequence. A crack can be seen cutting through the dirty bottom surface of the uppermost annual layer. The second annual layer (approximately $1.5 \mathrm{~m}$ thick) is split wide apart in the foreground but still intact in the background. Dark space at bottom is subglacial gap. Photograph taken with flash 24 September 1977. 
Observations in the early summer of 1979 provided information on the winter status of the main bergschrund. The wide, open gap floored by bedrock had been filled with snow over the previous winter. The deep cleft between the bedrock wall and the main glacier body (see Fig. 4) did not fill however; it was bridged. It was possible to gain access to the underside of the bridge at the north-western edge of the glacier, in early June (Fig. 14). The bridge, between 1 and $2 \mathrm{~m}$ thick, was beginning to sag into the void, leaving an indentation on the glacier surface above. Broad grooves and ridges on the underside of the bridge (Fig. 14) appeared to correspond to irregularities in the top of the rock wall, and suggest that the bridge layer moved downhill across the void sometime after its creation in the previous fall.

Later in the summer the bridge thinned and deformed sufficiently to crack, forming the year's first crevasse. Thereafter, melting of the snow filling the wide, rock-floored gap proceeded fairly rapidly. Once most of the young snow was gone, melting of the then-exposed up-glacier ice wall proceeded.

It is not known what happens to the flow-and-ablation system up-glacier of the bergschrund in winter. Intuitively, creep of the snow/ice mass should be retarded during the winter because of lack of basal melt-water lubrication. However, relief on the underside of the bridge described above suggests that some sliding of bridge snow occurred during winter and/or spring.

\section{Mass transfer across the bergschrund system}

The bergschrund system can be regarded as dividing the glacier into two independent ice bodies. Even though there is no surface crack for most of the year, subglacial ice layers remain perennially separated. Nevertheless, the large quantity of ice and firn blocks that litter the

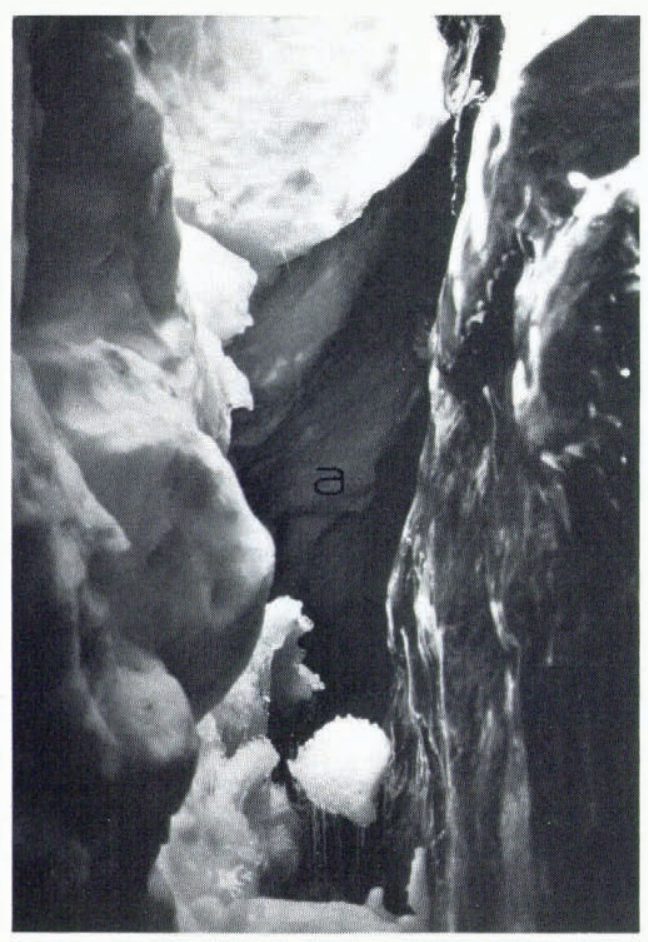

Fig. 14. Underside (a) of bridge covering the deep ice-bedrock gap shown in Fig. 4, looking south-east at the extreme north-west end of the bergschrund system. Bedrock cliff on right; glacier on left. Camera is pointing upward at about a $40^{\circ}$ angle. Note broad ridges and grooves on underside, trending from upper right to lower left, and slight convexity produced by sagging of the bridge. Icicles in middle foreground are about $0.3 \mathrm{~m}$ long. Photograph taken 2 June 1979. 
bergschrund system indicate that some ice is still transferred across the system. The blocks, up to $2 \mathrm{~m}$ across, are found mantling the uppermost part of the main glacier body adjacent to the main bergschrund, and form the floors of crevasses and subglacial gaps farther to the south-east (e.g. Fig. 8). They are apparently derived from folded, hanging, firn layers on the up-glacier side of the bergschrund system. Although no block-falls were actually observed (fortunately), cases were noted where up-glacier layers were hanging free in a vertical or even overhanging orientation, presumably soon to be detached (Fig. 15). Blocks that fall onto the main glacier body are later buried by snow and become part of that body. Blocks wedged between the glacier body and bedrock may be ground up by motion of the glacier or may melt and run down the rock; in any event some of that ice probably ends up as glacier sole.

Mass is also transferred across the bergschrund system in the form of water, which drips off the up-glacier ice and runs down the bedrock through the summer season.

\section{SUMMARY}

The above observations can be summarized by means of a general scheme in which the fate of a small mass of snow depends on where it was deposited on the glacier. Only snow deposited early in the snowfall/avalanche season need be considered, as late-season snow is liable to melt during the succeeding summer.

Avalanche snow dumped on the apex of the fan may travel down and across the bergschrund system or it may be deposited on or up-glacier of the system. Once deposited, it may be eroded by subsequent avalanches (likewise, snow from direct snowfall may be subsequently eroded). Any mass of snow above the bergschrund system that does persist will be buried by later snow,

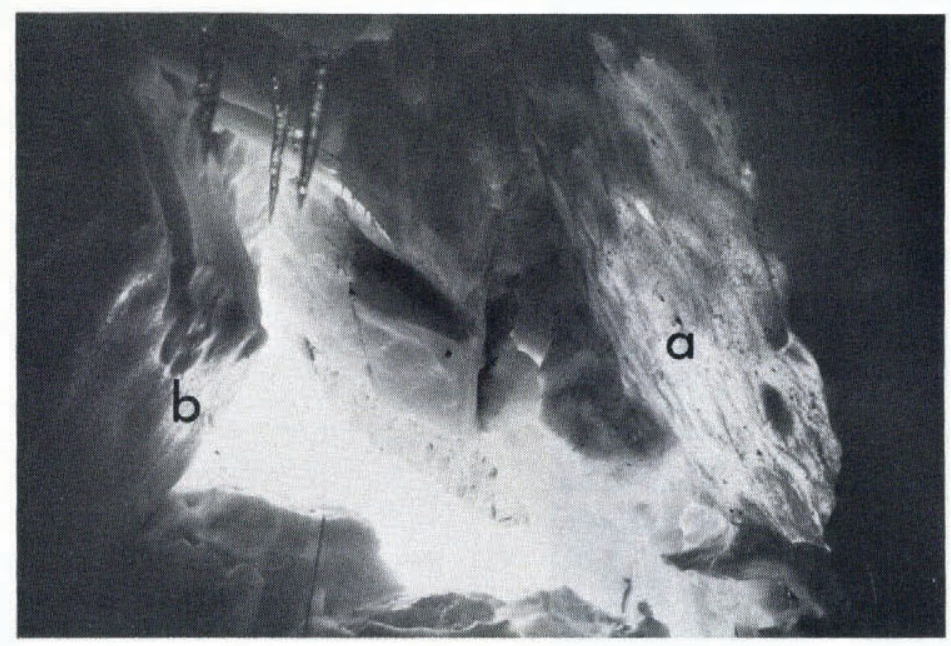

Fig. 15. Folded, hanging annual layer in subglacial gap, looking horizontally south-east (down-glacier direction is to left). The face (a) is the top surface of a layer which originally was juxtaposed with the bottom surface (b) of the next higher annual layer. Layer (a) has partly detached and folded downward to an overhanging orientation; in the meantime a crack has split the higher layer. Width of area in foreground is approximately $2.5 \mathrm{~m}$. Photograph taken 17 September 1978. 
and will travel englacially down-hill, roughly parallel to the bedrock surface beneath it (Fig. 12). Arriving eventually at an up-glacier ice wall somewhere along the bergschrund system, the snow, now metamorphosed into firn or ice, either melts and/or evaporates, or folds downward and breaks off, lodging between glacier ice and bedrock. Thereafter it may ablate during the succeeding summer or may be incorporated into the glacier sole.

Snow deposited directly on or over the bergschrund system will fall into open crevasses very early in the snow-fall season. Some of it will ablate the following summer. Later in the snow-fall season new snow will become part of the bridge over the system. Some of the bridge snow will later collapse into the void, some will ablate (from the bottom surface as well as top surface), and some on the down-glacier edge of the bridge may survive as part of the upper layer of the main glacier body.

Snow deposited just down-glacier of the bergschrund system will become part of the main glacier body, and will travel downward as the glacier flows.

Downward motion of the glacier results in displacement of the surface across the bergschrund system, which reaches a maximum at the end of the melting season. Since no displacement is evident in the following spring season, the surface drop-off is obviously offset each winter by a greater accumulation of new snow down-glacier of the bergschrund than upglacier of it. Deposition on the up-glacier side is limited, in a simple steady-state model, to the "space" provided by downward creep of the upper part of the cone (Fig. 16). Once that space is filled, and the angle of repose of avalanche snow is reached, excess snow will be transported farther down, past the bergschrund system.

\section{Generality OF PHENOMENA}

Hypotheses constructed from the observations herein and which can be applied to bergschrunds in general are as follows:

(1) Variations in rock-wall steepness, when present, constitute a control on bergschrund location.

(2) The wedge of snow and ice up-glacier of the bergschrund constitutes an independent accumulation, flow, and ablation system.

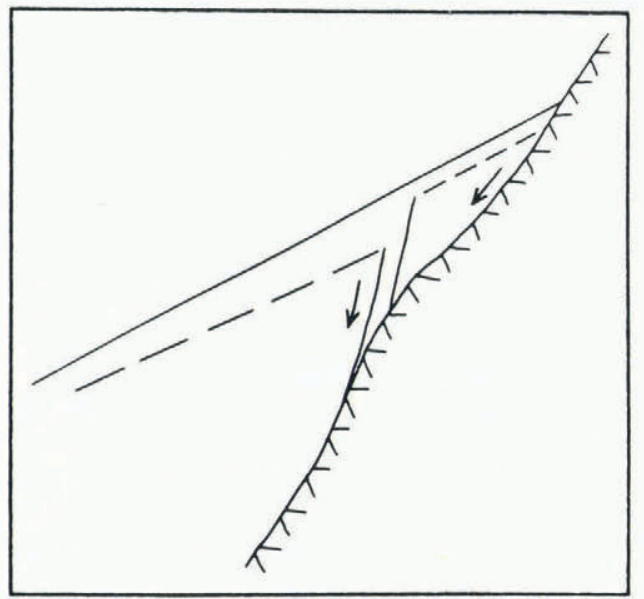

Fig. 16. Schematic sketch illustrating displacement of the glacier surface across the bergschrund. Solid line indicates surface at end of winter; dashed line is surface at end of summer. Arrows indicate direction of ice motion. 
(3) A downward component of flow in the main glacier body results in displacement across the bergschrund of the previous winter's snow layer; as a consequence, in the following winter more snow will accumulate immediately down-glacier of the bergschrund than immediately upglacier.

The glacier described here is somewhat atypical of glaciers heading at rock walls; nevertheless these hypotheses should be generally applicable to more normal cirque and valley glaciers. With regard to the first hypothesis, the influence of a bedrock step should depend not so much on whether the glacier is fed by avalanche or direct snow-fall, nor whether the glacier fills up a cirque or not, but rather on the height, steepness, and lateral extent of the step. Horizontal steps in glacier head-walls are common in Canadian Rockies due to stratification of the rocks; such steps presumably are less prominent in areas of massive and/or highly deformed rocks.

The validity of the second hypothesis likewise is independent of the form and nature of nourishment of the glacier. The mobility of the snow/ice wedge will depend on such things as the roughness of the rock, steepness, and amount of basal melt-water.

The amount of displacement across the bergschrund will depend mainly on the topography of the rock surface: displacement will be relatively high where the bergschrund is situated at a rock step and relatively low where it is situated on a smooth or straight head-wall. Form of the glacier should not be important. Winter restoration of a smooth surface profile across the (bridged) bergschrund is accomplished by avalanching in the case of the Mt Chephren glacier; observations in the Canadian Rockies indicate that most glaciers heading at rock walls are nourished to some extent by avalanches.

These hypotheses can be tested in part by simple observation at a variety of sites. Measurement of flow and ablation up-glacier of bergschrunds requires monitoring of reference markers. Search is in progress for sites where quantitative measurement can be conducted without undue hazard.

\section{ACKNOWLEDGEMENTS}

I am especially grateful to my field assistants Sylvia Forest and Cathy Langill for their secure belays in occasionally uncomfortable environments. Ms Langill also contributed ideas in the field and reviewed the manuscript. The manuscript benefited additionally from critical readings by Angus Ferguson and Mathew Duford. Field work was supported in part by Canadian N.S.E.R.C. grant A9026.

MS. received 11 May 1981 and in revised form 9 February 1982

\section{REFERENCES}

American Geological Institute. 1962. Dictionary of geological terms. Garden City, N.Y., Dolphin Books.

Battle, W. R. B. 1952. Contributions to the glaciology of north-east Greenland, 1948-49, in Tyrolerdal and on Clavering Ø. Meddelelser om Grønland, Bd. 136, Nr. 2, [second article].

Battle, W. R. B., and Lewis, W. V. 1951. Temperature observations in bergschrunds and their relationship to cirque erosion. Journal of Geology, Vol. 59, No. 6, p. 537-45.

Luckman, B. H., and Osborn, G. D. 1979. Holocene glacier fluctuations in the middle Canadian Rocky Mountains. Quaternary Research, Vol. 11, No. 1, p. 52-77. 
McCall, J. G. 1960. The flow characteristics of a cirque glacier and their effect on glacial structure and cirque formation. (In Lewis, W. V., ed. Investigations on Norwegian cirque glaciers. London, Royal Geographical Society, p. 39-62. (R.G.S. Research Series, No. 4.))

Theakstone, W. H. 1979. Observations within cavities at the bed of the glacier Østerdalsisen, Norway. Journal of Glaciology, Vol. 23, No. 89, p. 273-81.

Vivian, R. A., and Bocquet, G. 1973. Subglacial cavitation phenomena under the glacier d'Argentière, Mount Blanc, France. Journal of Glaciology, Vol. 12, No. 66, p. 439-51. 